\title{
Representation of Refugee Children in the German Children's Books "Zahira, Ein Mädchen aus Syrien" and „Neben Mir ist noch Platz“
}

\author{
Lilawati Kurnia ${ }^{1}$ \\ \{11ilac1910@gmail.com\} \\ ${ }^{1, \text { Universitas Indonesia }}$
}

\begin{abstract}
Refugees particularly those coming from countries embroiled in conflicts like Syria have posed problems for European countries and in particular for Germany as a country that has opened its borders to them. The problems are related to not only relocation but also integration into German society. While suffering from quite severe trauma due to wars and long treacherous journeys, refugees are required to adjust to new conditions and situations that are unfamiliar. Furthermore, many of these refugees are children who do not fully comprehend their new situations. The identity of refugee children is often described as a deplaced identity so that they are expected to leave the old identity and acquire a new identity voluntarily.This is demonstrated in German children's books which were written for integrating the children into the host country, namely „Zahira, Ein Mädchen aus Syrien“ (hereinafter ZEMS) and „Neben Mir Ist Noch Platz“ (hereinafter NMNP). These books build on identity constructions of refugee children, and this paper will further in a close reading method will show that the identity of the refugee children is considered as a social construction and could be altered by the new aquired language and culture. Through the concepts of representation by Hall this paper will shows that identity of children refugee in the books is constructed.
\end{abstract}

Keywords: refugee problems, German children literature, identity construction, refugee integration

\section{Introduction}

The world has witnessed how wars in Syria and other conflict-ridden areas have precipitated the migration of diverse nations to many other countries. The people who constitute these flows of migration aspire for a more peaceful and prosperous life and hope to protect their children from the brutality and suffering caused by wars. Different forms of media, namely printed, online, and electronic, have published daily reports about refugees. We hear stories about refugees struggling for survival by taking difficult and perilous journeys. They are forced to leave their homelands, homes, family members, and lives, which they have worked hard to build. They often have to undertake these dangerous journeys along with their 
children who may experience traumatic events along the way. Of course we do not want children to experience such things, but the reality is that these events happen up to today. serve as a bridge for dialogue and to promote empathy, mutual understanding, and even inspire readers to participate in actions related to saving refugees, particularly refugee children. Some writers of children's books have chosen to write about topics closely associated with refugee children to make this complicated issue more humane and moving for children readers.

Refugee children are often stigmatized as uninvited guests. Nevertheless, historically human migration can be traced all the way back to pre-civilization. There are many tales or mythologies about human migration, for example Odysseus and Aeneid by Virgil which tells the story about Aeneas who escaped from Troy to establish a separate dynasty. There are also many examples from the Indonesian context in which several tribes migrate or leave their hometowns (merantau) to gain recognition from their communities. Peter Kingsley [1], a correspondence for the Guardian on immigrant issues, asserted that "Personally, I feel that anyone who's on the move should be described as a migrant because migrant should be a neutral term that describes the act of movement, rather than the intention of the person who's moving." Leaving a country because of adverse and perilous conditions should be considered the normal thing to, and in this case Kingsley suggests that it is more precise to examine the act of movement than the intentions behind the movement.

Since 2015, there have been many children's books published, and the number reached a peak in 2016. However, in 2017 [2] the number of refugees dropped along with the decrease in children's books about refugees. The books that were published were always provided with book reviews and clear information in the publisher's catalogue as well as blogs and sites about children literature, for example whether or not the book is suitable for children and of which age group. Since 2015, the stories have been translated into Arabic, so that refugee children could quickly learn German language. However, after two years the publishing house stopped publishing Arabic translated versions because of the low sales. Although the books were already in Arabic, refugee parents did not seem interested to go to book stores with their children. However, German publishing houses did not give up, and they began translating fairy tales and children stories from various countries, such as Iran, and other Arabic-speaking countries into German. Thus, both the host and the guest have attempted to get to know each other and establish mutual understanding.

Children's books produce not only narrations that are in line with real circumstances but also experiences that are often too uncomfortable and horrifying to be talked about explicitly. In this sense, children's books for children of early years are written with many pictures and characters from the animal kingdom. Multicultural aspect in childrenn books could inspires students about cultures beyond the student's culture [3]. It also gives children the mutual feeling of belonging to a world, provides them with self esteem and develops empathy. Besides the long and treacherous journeys as well as suffering upon their arrival in Germany, refugee children have experienced things unimaginable for children in general, for example having to interact with foreign adults while not being able to speak German at all. These constraints are depicted in an online media in Germany, Süddeutsche, titled Wenn Sich Alles Fremd Fühlt [4] (When Everything Feels Foreign): "Mit einer neuen Sprache und fremden Kultur konfrontiert, versuchen die Kinder, Erlebtes zu verarbeiten und die Hürden des Alltags in der neuen Heimat zu meistern. Verlust, Angst, Ungewissheit - mit diesen Dingen müssen geflüchtete Kinder genauso fertig werden wie Erwachsene." (Confronted with a new language and culture, children have sought to overcome everyday challenges in their new homeland. Loss, fear, precarity - these are some of the issues that have to be faced by refugee children in 
the same way as adults). Adults also have to face the same issues, but they receive many forms of assistance to help adjust with the foreign culture. The two refugee children book, ZEMS [5] and NMNP [6] will be read and discussed accordingly to the concepts of Representation of Stuart Hall.

The integration of refugee children begins early when children enter preschool, respect for refugee culture is reviewed by Rhedding-Jones [7] regarding the use of the word "aunt" for teachers in preschool. In arabic culture the word auntie has more meaning than just a sister of father or mother, it is used to express respect of the elder one that has more experience and also knowledge. The lost of cultural root is often not included in many refugee policy especially for children. The focus of handling this topic has been more to the shifting of identity and couping with the new one that obtained in the new 'home'land. Guerero dan Tinker [8] stated that identity is formed as a social contruction, which can be interpreted that identity could be 'new'formed by contructing the person in the new home and culture.The problem of children refugee is more complex if they are coming as an URM (Unaccompanied Refugee Minors). As Carlson, Cacciatore and Klimek [9] has detected the lack of cultural congruence and expectation between the UMRs and the foster parents may increase the trauma in UMRs. How you transfer this situation and experience into a children book is the question of Haeming [10] who wrote an article in the german newspaper Frankfurter Algemeine Zeitung, and stated that many writer just simplified the problems because this is a book about children, but there are some who also experience the great lost during the last world war and displaced. Those writers wrote a book that she considers better to read by the UMR.

\section{Research Method}

Close reading method is a method which used in reading literature and signaling the way researcher in this field read a book. With a close, careful reading of each passage in the books, we can interpret the meaning of it. This method is often apply by literary criticism.

Stuart Hall's [11] representation is widely used to analyze the visual culture, because Hall has given us how to look on text which has visual elements. Representation has three different approaches to look upon the visualization that is, reflective, intentional and constructionist. In the case of two children book the constructionist is the way to analyze them because the identity of children shown in the books is a construction. Before Hall, Paul du Gay [12] has shown us in his method of analysing text, the Circuit of Culture, how the meaning convey to the audience not only the "factual" meaning but also the social meaning.

\section{Results And Discussion}

Thefirst difficulty is the German language which the refugee children must learn, and it often becomes the main issue in children's books about refugees. In the children's books that bring up refugee themes, many depict the initial misunderstanding emerging out of the meeting of children from various distinct cultures, especially as different languages serve as a communication barrier [13]. In the children's book NMNP, the following lines are discovered: „Aisha hat zwar sehr schnell Deutsch gelernt, aber Fehler macht sie immer noch“ (Aisha does learn the German language quickly, but she still makes mistakes here and there" [2], and in ZEMS: „Weil sie in Syrien eine komische Sprache sprechen“, sagt Sascha. ..."Du meinst 
sicher eine andere Sprache, Sascha!“ [1] („Because they speak a weird language in Syria“, said Sascha. "What you mean is in another language, Sascha!"). Nonetheless, both children are aware that they need each other because it is not only the refugee children who want to learn the host country's language, but the German children also want to learn the foreign language. The children's desire is described in a language that can be understood by children and illustrated in pictures that children like.

The identity construction of refugee children like Zafira is made to resemble German children, who are brave and nimble. For instance, she can swim and climb trees, activities that are prohibited for women in her home country. Alima, another refugee child, is not allowed to participate in gymnastics or swimming by her father, but Zafira's mother explained that it was Zafira's nimbleness that allowed her to survive when getting on board of the refugee boat. It was particularly helpful as well in facing possible danger in the middle of the ocean as boats might sink. Zafira could survive, because she could swim. „Ich finde es gut, dass hier Jungen und Mädchen die gleichen Rechte haben und in der Schule di gleichen Sachen machen dürfen", sagt Alima (I think it is constructive that boys and girls have equal rights here, and in school they can do the same activities). Alima's mother also says: „Wir leben in einem fremden Land, das uns gastfreundlich aufgenommen hat. Wir haben zu essen. Wir leben in Frieden...Wir sind in Sicherheit...Wenn sich unsere Kinder auf Dauer hier wohlfühlen sollen, müssen wir einige unserer Gewöhnheiten verändern. Und wir müssen die Sprache unserer neuen Heimat lernen, damit wir uns besser verständigen können" (We live in a foreign country, which has welcomed us with open arms. We can eat. We live in peace.. In safety.. If we want our children to eventually feel comfortable, we must alter our habits. And we must learn the language of our new home, so that we can build mutual understanding"). The image of the refugee that is described here is one who follows the local culture and learns German voluntarily.

Meanwhile, Aisha is portrayed in a more realistic manner by demonstrating how tradition and culture are maintained despite its conspicuousness, from the perspective of the Germans, such as Steffi's friend and the parents. For example, during Steffi's birthday party, only her girlfriends from class, including of course Aisha, were invited. However, Aisha once again attended with her brother, Jussuf, and this made Steffi angry. She prohibited Jussuf from coming into the house. Aisha then went home with Jussuf, because she did not want to attend the party on her own, as it was not part of the tradition. Steffi also did not know that asking Aisha's brother to leave was offensive, because she was unfamiliar with Arabic culture. This led to the dissolution of their friendship. For three weeks they did not speak to each other, because each of them felt that they had done nothing wrong and did not want to appear weak in front of the other. When Aisha eventually approched Steffi, it was only to tell her that she and her family had to move to another city because their status as asylum seekers had not been approved. This is part of the everyday reality of the refugees to obtain asylum. They must go through several stages that require repeated verification. Obtaining a legal asylum status is the aspiration of refugees, so that their existence in Germany is guaranteed. This stark difference is expected from a writer like Paul Maar who incorporates elements of critique against real circumstances in Germany, namely the rise of the ultra-right wing group that often attacks the refugees.

To provide an account of refugees, particularly refugee children, in a book of course requires going through several stages to ensure that the book is appropriate for children. Nevertheless, these stories have to include portrayals of the tragic and frightening incidents experienced by children, for example how they must escape by land, such as Aisha, and by sea, such as Zafira, as well as the long and treacherous journeys. Paul Maar, the writer of 
Neben Mir Ist Noch Platz, is a famous children's book writer. His books have received many awards, such as German Youth Literature Prize, the Austrian State Prize, and the Brothers Grimm Prize of the State of Berlin. However, the first edition of the book was heavily criticized as Maar described real-life events happening to a refugee family from Lebanon who were attacked by the ultra-right wing group. Their house was burned down, so the family decided to return to Lebanon after the war ended. Many believed that Maar's depiction may frighten the children who read the book, and it also seems to imply that refugees must be handled with violence in order for them to return to their own countries. Thus, the traumatic experience of war in their home countries repeats once again.In addition to this incident, there was a misunderstanding with her best friend, Steffi, and eventually she had to move with her family to a new city because their asylum status was not processed. Such incidents are part of the everyday reality of refugees and their children. On that note, Paul Maar has written a children's book that is close to reality, not one that merely emphasizes on the pleasant and comfortable situations for refugees. Nevertheless, Maar wants to emphasize that for most German people, the arrival of refugees is not perceived as a burden but as new forms of knowledge that widen their horizon about other cultures. This is why Maar's book ends with the arrival of a new refugee child and Steffi welcoming her in the same way she welcomed Aisha. „Steffi nickt ihr zu. Sie deutet auf den leeren Stuhl und sagt:"Neben mir ist noch Platz!“ (Steffi nodded her head. She pointed to an empty chair and said: „There's still an empty spot next to mine!“").

On the other hand, Scheffler's children's book is much lengthier than Maar's. This is because there is a part that explains in details about Zafira's hometown in Aleppo, Syria. There is even a map showing the cities in Syria and the land route taken by Zafira to Turkey. The difficulty and danger of the journey, especially from Turkey, taken by Zafira and her mother are explained including how they had to get on board of an illegal ship which held many refugees. They were also not dropped off on the shores but into crowded small boats which sank. It was fortunate that Zafira could swim to the shores with her mother. In their new and foreign country, Zafira is described to quickly interact with her friends including Anna. They can play together and Zafira quickly masters the German language. In addition, Zafira serves as a translator for new refugee families. For example is Alima, who then becomes dependent on Zafira. The construction of Zafira's identity as a refugee child is one who is completely happy and glad to be in Germany. There are not any complicated problems in Germany that could not be resolved. Even Zafira's father eventually joined them in Germany, and the family was reunited. Zafira experienced repeated episodes of joy. The book also ends on a hopeful note, suggesting that it is important to make Germany their new homeland. „Für ein neues Leben in einem neuen Land. Mit Frieden. Mit neuen Nachbarn, neuen Freunden. Eine echte neue Heimat vielleicht?“ (For a new life in a new country. In peace. With new neighbors and new friends. Perhaps a new homeland?) (Scheffler:96).

\section{Conclusion}

Overall, both children's books bring up the theme of refugees to portray the experiences refugee children; nevertheless, they differ in some aspects. In Scheffler's book, the emphases are on the treacherous journey and the portrayal of refugee children. Zafira is portrayed to have many resemblances with German children. She has initiative, courage, nimbleness, because she can swim and climb trees. Zafira can also communicate directly with Anna whom 
she first met when Anna was saved by Zafira when she got locked in the changing rooms. Meanwhile, Paul Maar portrays the interaction between Aisha and Stefii in a more intense manner. The book depicts not only the harmony between these two different children but also misunderstanding caused by their distinct cultural backgrounds. Thus, the identity of refugee children in Scheffler's appears ideal and constructed from a German perspective, while the identity construction in Maar's is not perfect. Children often get into fights and experience conflicts, but this is what is required so that they can learn to face the same issues when they later become adults.

\section{References}

[1] R. Kinna, "The Best Books on Anarchism | Five Books Expert Recommendations," Five Books. 2018.

[2] "Children's Authors Take On the Refugee Crisis - The New York Times.".

[3] S. F. Steiner, C. P. Nash, and M. Chase, "Multicultural Literature That Brings People Together," Read. Teach., vol. 62, no. 1, pp. 88-92, 2008.

[4] "Aktuelle Nachrichten, Hintergründe und Kommentare - Süddeutsche." .

[5] "Zafira - Ein Mädchen aus Syrien_ Schulausgabe_ Ursel Scheffler, Jutta Timm 9783867601931 Amazon.”.

[6] "Inhalt," pp. 1-38.

[7] "Critical Multiculturalism_Theory and Praxis - Google Books." .

[8] A. L. Guerrero and T. Tinkler, "Refugee and displaced youth negotiating imagined and lived identities in a photography-based educational project in the United States and Colombia," Anthropology and Education Quarterly, vol. 41, no. 1. pp. 55-74, 2010.

[9] B. E. Carlson, J. Cacciatore, and B. Klimek, "A risk and resilience perspective on unaccompanied refugee minors," Soc. Work (United States), vol. 57, no. 3, pp. 259-269, 2012.

[10] "Kinderbücher über Flucht, Krieg und Fremdsein." .

[11] "Representation | SAGE Publications Ltd."

[12] "Production of Culture_Cultures of Production _ SAGE Publications Inc.".

[13] K. Saddhono, A. Amalia, I. K. Sudarsana, and A. Indahingwati, "Multimedia Use For Beginner Level of Teaching Languages For Deaf Children: Study in Special Schools in Surakarta," in Journal of Physics: Conference Series, 2019, vol. 1254, no. 1, p. 12060. 